\title{
THE CITIZENS' COMMITTEE AND COMIC-BOOK CONTROL: A STUDY OF EXTRAGOVERNMENTAL RESTRAINT
}

\author{
JoHN E. Twomex*
}

No other medium of American popular culture has been subjected to such widespread, vehement, and continuing attack as the so-called comic-books. While controversies about the relationship between juvenile delinquency and crime themes in movies and radio have raged and subsided, the public outcry against crime and horror comic-books has persisted and now seems to have assumed the character of a permanent, grass-roots, citizens' crusade. Reflecting and perhaps reinforcing this unique development is the fact that these comic-books have, in recent years, been investigated by three congressional committees; ${ }^{1}$ they have been made the subject of a provocative and widely publicized book; ${ }^{2}$ as a product of American culture, they have become notorious and have caused embarrassment abroad; ${ }^{3}$ and lastly, their elimination has become the cause célèbre of women's clubs, ${ }^{4}$ church groups, ${ }^{5}$ and community action organizations. It is with a study of the organization and dynamics of one of these last-mentioned groups, the Citizens' Committee for Better Juvenile Literature of Chicago, Illinois, that this paper is concerned.

Requisite to a full understanding of the Committee is an appreciation of the history of the comic-book in American culture. ${ }^{6}$ The prototype of the modern comicbook was the six by sixteen inch booklet of Mutt and Jeff daily newspaper strips, issued by the Chicago American in IgII as a premium to increase circulation. Evolution was slow, however, and the next step did not come until 1929, when a tabloidsized booklet called The Funnies was published, marking the first time that comics

* M.A. Communication, University of Chicago, 1955.

The Communication curriculum is a new field of study in the Social Science Division at the University of Chicago which involves the investigation of the processes and effects of interpersonal, group, and mass communications. Mr. Twomey is the third University of Chicago graduate to receive this degree.

${ }^{1}$ Crime and horror comic-books have figured in investigations conducted by the Senate's Special Committee to Investigate Organized Crime in Interstate Commerce (1950); the House of Representatives" Select Committee on Current Pornographic Materials (1952); and the Senate Committee on the Judiciary's Subcommittee to Investigate Juvenile Delinquency (1954).

${ }^{2}$ Frederic Wertham, Seduction of the Innocent (1954).

3 See, c.g., Chester Bowles, Ambassador's Report 297 (I954).

'E.g., the General Federation of Women's Clubs, in its 1954-1956 program, emphasizes the elimination of "objectionable" comic-books and urges its members to form and support community committees on comics. See General Federation of Women's Clubs, Unity in the Community 35 (1954).

'E.g., the National Organization for Decent Literature, which was launched in 1937 by the Roman Catholic Church and which has become the largest and most powerful extralegal literary censor in this country, has devoted itself largely to the suppression of "objectionable" comic-books. See Hearings Before the Select Committee of the House of Representatives on Current Pornographic Materials, 82d Cong., 2d Sess. 76 (1952).

- For definitive treatment of this subject, sce Colton Waugh, The Comics (1947). 
were both especially drawn and sold independent of a newspaper connection. This innovation seemed to have promise, and the subsequent success of Famous Funnies, a compilation of popular newspaper comic-strips, in 1934 and New Fun, a four-color, sixty-four page collection of original comic material, in 1935 established the pattern for the industry.

The next significant development occurred in 1937 with the publication of $D e$ tective Comics, which signalled the birth of comic-book heroes of a type never before seen in newspaper comic-strips. Some ramifications of this new trend are described by the historian of comics in America, Colton Waugh:"

These newspaper stars, however, were to be written off as sissics by the new hero of the comic books, who was to lift the whole comic-book industry in his immense arms and blow it into an extravaganza new to publishing, new to America, and new to the world. It wasn't a bird, it wasn't a bee, it was Superman.

Heroes and heroines of supernatural strength and their struggles against the "forces of evil" remained the popular theme of the best-selling comic-books during the war years; but in 1946, comic-books began to exhibit a growing preoccupation with themes of crime and violence, featuring, in many instances, sexually suggestive and sadistic illustrations. From this, it was but a short step to the comic-book of horror stories, first introduced in $195^{\circ}$.

These great changes in subject matter prompted observations that comic-books were no longer comical, but rather were handbooks on crime and violence which promoted juvenile delinquency. Sterling North, one of the first to publicly criticize comic-books as being harmful for children, in an editorial written for the Chicago Daily News in 1940, described the emergence of comic-books as "a poisonous growth" and called upon parents and teachers to make better books available to counteract their "graphic insanity" and "sadistic drivel."8 But, although other persons and groups may have adverted to the situation, the war years brought more urgent matters to the fore, and the comic-book issue faded from public attention.

The leader of the anti-comic-book movement in the post-war years has been Dr. Frederic Wertham, a New York psychiatrist. In the winter of 1945-1946, Dr. Wertham began his investigation into the influence of comic-books on the behavior of children, and since that time, he has written extensively in popular magazines ${ }^{\circ}$ as well as testified before legislative committees in this country and in Canada on his findings $s^{10}$ - which were adverse. His formulations and dramatic presentation may,

Id. at 343 .

${ }^{8}$ Chicago Daily News, May 8, 1940, p. 21, col. 4.

'See, e.g., Wertham, The Comics-Very Funny, Saturday Review of Literature, May 29, 1948, p. 6; What Your Children Think of You, This Week, Oct. 9, 1948, p. 4; What Are Comic Books?, National Parent Teacher Magazine, Mar. 1949, p. 16; What Parents Don't Knosv, Ladies' Home Journal, Nov. 1953, p. 50; Blueprints to Delinquency, Reader's Digest, May 1954, p. 24; and It's Still Murder, Saturday Review of Literature, April 9, 1955, p. I1.

${ }^{10}$ See, e.g., Hearings Before the Subcommittee to Investigate Juvenile Delinquency of the Senate Committee on the Iudiciary, 83d Cong., 2d Sess, 9r (1954). 
in fact, be said to have been the factor most largely responsible for such widespread anti-comic-book sentiment as has been aroused at local and national levels. ${ }^{11}$

The Citizens' Committee for Better Literature had its inception in a meeting called by the Chicago Police Department's Censor Bureau in February r954. This meeting, which brought together civic and religious community leaders, was intended to publicize the increasing flow of "objectionable" literary materials into the city and to tell of the handicaps the police faced in dealing with it. At its conclusion, the Committee was organized, and representatives from such diverse groups as the Chicago Region PTA's, the Council of Catholic Women, the Council of Church Women of Greater Chicago, the Woman's Auxiliary of the Episcopal Diocese of Chicago, and the Illinois Federation of Women's Clubs made up the provisional executive committee.

Despite the apparent initial enthusiasm, however, the Committee languished. Fewer than nine members attended any of the five meetings which were held before the Committee quietly expired. Besides the usual frictions which stem from attempts to organize diverse groups into civic action groups, there seem to have been two additional factors which may explain this failure: the reluctance of both the police and clergy to become formally involved with the Committee, and the absence of some medium through which to acquaint the wider community with both the "menace" the Committee saw in comic-books and the measures with which it proposed to cope with it.

During the six months which intervened between this first abortive attempt to organize the Committee and its rebirth in the fall of 1954 , however, events occurred on both the national and local scenes which provided the impetus needed for the kind of city-wide anti-comic-book crusade envisioned by the original members of the Committee. The appointment of the Subcommittee to Investigate Juvenile Delinquency of the Senate Committee on the Judiciary helped to focus nation-wide attention on the proliferation of crime and horror comic-books and the charges that they contribute to, if not directly cause, juvenile delinquency. ${ }^{12}$ The hearings held in New York, the seat of the comic-book industry, were the most intensive probe that has yet been made into comic-books and their publishers. Reports in the press and national magazines carried some of the more sensational testimony all over the country. ${ }^{13}$ Illustrative is this exchange between Senator Kefauver, Chairman of the subcommittee, and Mr. William Gaines, publisher of the Entertaining Comic Group: $:^{14}$

\footnotetext{
${ }^{12}$ Dr. Wertham's role in the anti-comic-book crusade has by no means escaped criticism. E.g., "Wertham's dark picture of the influence of comics is more forensic than it is scientific and illustrates a dangerous habit of projecting our social frustrations upon some specific trait of our culture, which becomes a sort of "whipping boy" for our failure to control the whole gamut of social breakdown." Thrasher, The Comics and Delinquency: Cause or Scapegoat, 23 J. Educ. Sociolocy I96 (1949).

12 Hearings, supra note 10 , at 2.

${ }^{19}$ Ses, e.g., Time, Sept. 27, 1954, p. 77.

16 Hearings, supra note 10 , at I03.
} 
Senator KEFAUVER. Here is your May 22 issue. This seems to be a man with a bloody ax holding a woman's head up which has been severed from her body. Do you think that is in good taste?

Mr. GAINES. Yes, sir; I do, for the cover of a horror comic. A cover in bad taste, for example, might be defined as holding the head a little higher so that the neck could be seen dripping blood from it and moving the body over a little further so that the neck of the body could be seen to be bloody.

Coincident with these hearings came the publication of Dr. Wertham's book, Seduction of the Innocent, ${ }^{15}$ which recapitulated the findings of his seven years of research. In it, he detailed the case against comic-books and described the dynamics of the fight that he and others had been waging in this cause. The book was widely reviewed and acclaimed, and it apparently had considerable impact. In naming it "the most important book of I954," the editor of the National Education Association Journal said:16

This book, if read by the great body of American citizens, would help to build the understanding essential to the growth and survival of our free democratic society. . . . This volume should be in the library of every parent, teacher, preacher, and juvenile judge and in school and public libraries. Let local education associations and the PTAs see that it is widely read and that the community takes steps to protect children from the menace it describes.

On the local level, the owner and publisher of the Southtown Economist, a fiftyyear old, south-side Chicago, community newspaper, read Seduction of the Innocent and directed his editor to start an anti-comic-book campaign. Soon, twenty letters, with copies of crime and horror comic-books enclosed, were mailed to various neighborhood clergymen, each of whom was asked to write a condemnatory review of the comic-book that he had received. These reviews were to loom large in the campaign, which broke shortly thereafter with a banner headline that read "The Shocking Story of CRIME AGAINST YOUTH."17 In telling the "shocking story" to its 155,000 readers, the Economist quoted liberally from Wertham's book, recalled the details of the brutal slaying of a seven-year-old neighborhood boy by a comicbook-reading teenager, and printed a review of a horror comic-book which had been submitted by a local Lutheran minister.

Among the news items which were given prominent play during the campaign were: a comic-book burning rally sponsored by a community police captain; ${ }^{18}$ a children's crusade which was circulating petitions calling upon the president for federal legislation to ban comic-books; ${ }^{19}$ an anti-comic-book resolution adopted at the summer convention of the National Council of Juvenile Court Judges; ${ }^{20}$ a report of the state attorney's interest in the campaign and his promise to investigate comicbooks; ${ }^{21}$ and a release by the Chicago Retail Druggist Association urging its mem-

\footnotetext{
${ }^{15}$ WERTHAM, op. cit. supra note 2.

${ }^{10}$ Morgan, Editorial, 43 Nar. Educ. Ass'N J. 473 (1954).

${ }^{27}$ Southtown (Ill.) Economist, July 18,1954, p. 1 .

${ }^{18}$ Id., Aug. I, 1954, p. I, col. 4 .

${ }^{20}$ Id., Aug. II, I954, p. I, col. 4 .

${ }^{10}$ Id., July 28, 1954, p. 1, col. 5.

${ }^{21}$ Id., Aug. 18, 1954, p. 1, col. 4 .
} 
bers to refuse to accept "objectionable" literature for sale in their stores. ${ }^{22}$ Throughout the eight weeks of its front-page campaign, then, this was the pattern to which the Economist adhered: large type headlines, comic-book reviews, and stories of community action.

Sensing the need for an organization to sustain the indignation of its aroused readers and to channelize it into effective action, the Economist extended its full support to an effort then being made to revive the moribund Citizens' Committee for Better Juvenile Literature. Articles concerning the Committee appeared, and news of its impending reactivation and reorganization was widely broadcast. ${ }^{23}$ Shortly thereafter, at two well-publicized and well-attended meetings, the Committee was formally re-launched, complete with a board of officers, a set of by-laws, committees, and a program of action. Thus, a somewhat fortuitous combination of national and local developments which focused attention on the comic-book problem helped to create the atmosphere necessary for the resuscitation of this community action group.

The guiding force behind the Committee, who engineered its reorganization and who now directs its activities as chairman, is Mrs. Robert V. Johlic. Mrs. Johlic had been a representative to the former Committee from the Council of Catholic Women of the Archdiocese of Chicago, with which organization she had, for six years, participated in and directed parish-wide "decency crusades" in cooperation with the National Organization for Decent Literature. Her perceptions of the problems involved in the control of comic-books and other media (i.e., pocket-size books and magazines) have been important factors in formulating the policies and directing the activities of the Committee. She regards the failure of the comic-book publishers to set up an effective self-censoring operation in $194^{24}$ as proof enough that civic action groups are the only answer to the comic-book problem: ${ }^{25}$

The publishers of all this junk have promised time and again to police themselves, but they won't do it. Right now they're talking about appointing a $\$ 40,000$ a year judge to censor their own material. They've made promises before. The smutty literature still comes out.

Nor does she regard the many state laws and city ordinances against indecent literature as an effective weapon in this fight: ${ }^{26}$

Many cities and states have tried banning the stuff, but the Supreme Court has always thrown out the law. The only way to get rid of material like this ... is to make it unprofitable to publish it, and that means educating the parents so that they know what's suggestive and what isn't.

But, while recognizing Dr. Wertham as an authority on the detrimental effects of

${ }^{22}$ Id., Aug. 22, 1954, p. $\mathrm{x}$, col. 5.

${ }^{23}$ E.g., id., Aug. 4, 1954, p. 1, col. 5.

${ }^{24}$ See testimony of Henry Edward Schultz, Hearings, stupra note ro, at 69 .

${ }^{25}$ Chicago Sun-Times, Aug. 29, 1954, p. 18, col. 1 .

${ }^{20}$ Ibid. 
comic-books, Mrs. Johlic disagrees with his view that all comic-books should be banned: $:^{27}$

Wertham says abolish all comic-books. We don't say this. We don't want to force anyone out of business. We want to educate and show people what poor stuff is available so they will demand better magazines and comics. We believe, to borrow the Marshall Field store slogan, that they will "give the lady what she wants" when they realize what it is she wants.

The formal aims of the Committee, as set forth in its by-laws, are: ${ }^{28}$

I. To promote the welfare of children and youth in home, school and community through the medium of good literature.

2. To encourage the publication and dissemination of literature which will contribute to the intellectual, social, cultural and spiritual growth of children and youth.

3. To work actively for elimination from publication and circulation of such literature as may be detrimental to, or have no beneficial value in, the intellectual, social, cultural or spiritual development of children and youth.

The activities of the Committee promoting the more positive aspects of its work, as stated in its first and second aims, are directed by its standing committee on Operation Good Reading, one member of which is a librarian of children's books at the Chicago Public Library. Through its efforts, pamphlets on library service and items, such as One Hundred Books of Lasting Value for the Child's Home Library, have been distributed, and some members of the Committee have been persuaded to enroll in a program for parents, consisting of one class in Reading Guidance for Children and another in Reading Guidance for the Adolescent, both of which are jointly sponsored by the Library and the Illinois Congress of Parents and Teachers. The Committee also helps to publicize the Library's various programs designed to encourage good reading among children, the most popular and successful of which have been the Children's Hour, an integrated, weekly program of films, recordings, and story telling, and the Vacation Jamboree, a summer-time program involving book discussion groups and reading accomplishment awards. ${ }^{20}$

The greater part of the Committee's activity, however, falls under its third objective-i.e., the elimination of "detrimental literature," which has been interpreted to include pocket-size books, popular magazines, and "girlie" magazines as well as crime and horror comic-books. The technique adopted has been that of the National Organization for Decent Literature: a wide variety of popular publications is regularly purchased; these are read by volunteers who judge them in accordance with

${ }^{27}$ Interview with Mrs. Robert V. Johlic, Scpt. 1954. It should be noted, on the other hand, that Dr. Wertham has analogized the approach of such civic movements as the Committce to the sampling of all the items in a neighborhood drugstore to protect the community. He asks "What mtst happen to the minds of children before parents will give up these amatearish extra-legal committce actilities and ask for efficient legal, democratic protection for their children?" WERTHAM, op. cit. supra note 2, at 328.

${ }^{28}$ Citizens' Committee for Better Juvenile Literature, By-Laws art. II.

${ }^{20}$ For a detailed description of Library programs, see Chicago Public Library, Libraky Service to Children and Young People (1955). 
established criteria; a list of publications judged "objectionable" is regularly promulgated; and this list is then distributed to organized teams of surveyors who visit neighborhood retail outlets and request that listed items be removed from display and not be sold. Due to the inexperience and limited number of its members, the Committee has often been forced to use NODL lists, ${ }^{30}$ but a volunteer reading program has been inaugurated and the following "code of objectionability" formulated ${ }^{31}$

\section{Procedure for Voluntary Readers}

May we first impress upon you that all publications you may read should be judged only as suitable reading for Youth. We ask you not to be prudish in your judgment. Remember, it will be your reasons for declaring the book objectionable that will be sent to the individual publisher.

I. Each story must be carefully read and every advertisement read thoroughly.

2. Examine the book for the following reasons:

I. Format
A. Cover
B. Print
C. Color

2. Contents
A. Advertisements
I. Sex
2. Gambling
3. Weapons
B. Stories
r. Plot
a. Horror
b. Illicit love or lust
c. Gambling
d. Gruesome crime

2. Moral tone
a. Religious or racial bias
b. Glorification of crime

3. Vocabulary
a. Blasphemous
b. Obscene
c. Preponderance of slang

C. Illustrations
I. Indecent
2. Horror
3. Gruesome

3. Cite page reference to specific objection.

4. General comment.

${ }^{30}$ Two types of NODL lists are circulated: lists formulated at the local level, usually by survey groups, found in large urban dioceses; and a national list, promulgated, for the past six years, by the Archdiocese Council of Catholic Women of Chicago under the supervision of Mrs. Robert V. Johlic in her capacity as chairman of the Council's annual Decency Crusades.

${ }^{31}$ Citizens' Committe for Better Juvenile Literature, Procedure for Volunteer Readers (1954). 
A number of problems have arisen in the administration of this program. Apart from raising funds with which to purchase the publications, which is a pressing and continuous one, enlisting and maintaining volunteer readers presents, in itself, myriad difficulties. One of these is described by Mrs. Johlic: ${ }^{32}$

We've also had a problem with some of our readers (women who volunteer to appraise the current material) who are too shy. I mean, you feel kind of silly riding home on the IC studying a copy of Nude Models or Weird Horror Tales. We're getting around that problem by providing each of the readers with a large brown envelope to hide the magazines they're studying.

Again, volunteer readers sometimes misconstrue the criteria of appraisal. For example, one volunteer reader found "objectionable" the Mentor pocket-book edition of Barnard Pares' Russia; ${ }^{33}$ the report submitted stated that passages in this book described conditions in Russia that were, according to the Committee's code, objectionable. ${ }^{34}$

In surveying retail outlets, other problems are encountered. Frequently, retail dealers profess a will to cooperate with the surveyors but plead inability to do so because of the "tie-in" practices of the distributors, which they hesitate strenuously to resist for fear of inviting discrimination in subsequent dealings. ${ }^{35}$ The denial that this practice is prevalent in the Chicago area by an official of the major distributing company there, ${ }^{36}$ however, would seem to indicate that this claim by many retailers may be unfounded. Nevertheless, a bill to prohibit "tie-in" sales, sponsored by the Committee, has been introduced into the Illinois state legislature and enacted into law. ${ }^{37}$

Reports from surveyors also tell of "cooperative" retailers who remove "objectionable" publications from their shelves at the request of Committee members, only to return them after the surveyors have gone. There have also been instances when retailers unequivocally declined to cooperate with surveying teams. Only once, however, in its first year of operation, has the Committee found it necessary to call upon the Chicago Police Censor Bureau to exert pressure to enforce compliance. ${ }^{38}$ This willingness of the Police Censor Bureau to support the Committee's activities, incidentally, is perhaps one of the Committee's most potent instruments of persuasion.

In addition to its surveying activities, the Committee maintains close liaison with other organizations engaged in combatting "objectionable" literature, some of which look to the Committee for leadership, and others of which carry on separate campaigns. Among these organizations are the Veterans of Foreign Wars, the Chicago Retail Druggist Association, the Camp Fire Girls, the Illinois Federation of Temple

\footnotetext{
${ }^{32}$ Chicago Sun-Timcs, Aug. 29, 1954, p. 18, col. I.

${ }^{34}$ Interview with Mrs. Robert V. Johlic. May 1955.

${ }^{33}$ Barnard Pares, Russia (1943).

${ }^{35}$ Ilid.

${ }^{36}$ Intcrview with Mr. Herbert B. Fried, Charles Levy Circulating Co., April 1955.

${ }^{37}$ S. BiLt No. I1 8, 6gth Gen. Ass., Ill. (1955). See Southtown (IIll.) Economist, July 3, 1955, p.

${ }^{38}$ Intervicw with Mrs. Robert V. Johlic, May 1955.
} I, col. 6 . 
Sisterhoods, the Illinois Youth Commission, the Grandmothers' Club of Chicago, the Association of University Women, the Chicago Region PTA's, the Woman's Auxiliary of the Episcopal Diocese of Chicago, the Illinois Council on Motion Pictures, Radio, Television, and Publications, the General Federation of Women's Clubs, and the National Organization for Decent Literature. The liaison, and in some cases, interconnecting leadership, ${ }^{39}$ among these groups makes for more unified action and introduces a self-sustaining element into the anti-comic-book campaign.

While any facile evaluation of the activities of the Committee is precluded by its newness, the complexity of the problem with which it is dealing, and one's own moral and policy judgments, certain conclusions can fairly be drawn. Like many other extralegal groups organized to cope with what are felt to be socially abhorrent themes in our printed media, the Committee operates on the following premises: that there exist large quantities of inexpensive publications not suitable for young readers; that the nature of their contents is easily discernible by ordinary adult readers, since no special skills are necessary to distinguish between "good" and "bad"; that they are the products of publishers who are either unaware or contemptuous of "true" public tastes; that although laws against obscene literature may be of some value, the subleties of these media coupled with certain adverse high court decisions have rendered them practically impotent; and that an aroused, educated, and activated "public opinion" is the only force that can halt the dissemination of "objectionable" materials to children.

Since the popular appeal of the Committee's campaign is that literature must be "cleaned up" for the sake of children, the great majority of its members is, understandably, women, and to the extent that its campaign has been identified as a "women's club project," it has suffered from the lack of prestige and assistance that the interest of men might have afforded. On the other hand, however, this approach has gained the Committee at least indirect support in another quarter. In the Interim Report of the Senate subcommittee investigating juvenile delinquency, Senator Kefauver stated $:^{40}$

To achieve [the elimination of detrimental literature], it will require continuing vigilance on the part of parents, publishers and citizens' groups. The work that has been done by citizens' and parents' groups in calling attention to the problem of crime and horror comics has been far-reaching in its impact.

The interest of our young citizens would not be served by postponing all precautionary measures until the exact kind and degree of influence exerted by comic books upon children's behavior is fully determined through careful research.

The Citizens' Committee for Better Juvenile Literature, for the time being at least, seems to have arrived.

${ }^{30}$ E.g., Mrs. Robert V. Johlic, chairman of the Committee, has close links with the National Organization for Decent Literature, see note 30 supra, and is chairman of publications for the Illinois Council on Motion Pictures, Radio, Television, and Publications.

subcommittce to Investigate Juvenile Delinquency of the Senate Committec on the Judiciary, Comic Books and Ituenile Delinquency, Intcrim Report, 84th Cong., Ist Sess. 33 (1955). 